\title{
RESENHA
}

\section{ALBERTO MARSICANO, CRONISTA DO INSÓLITO}

Referência da obra resenhada:

MARSICANO, Alberto. Crônicas marsicânicas. Porto Alegre: L\&PM Editores, 2007.

André de Sena ${ }^{1}$

São Paulo e o Brasil perderam, no último dia 18 de agosto de 2013, um de seus mais talentosos cronistas (ainda a ser descoberto pelo público e crítica), o também músico, tradutor e filósofo Alberto Marsicano, morto aos 61 anos, desaparecimento registrado em jornais de grande circulação e sites especializados, os quais lembraram sua importância como introdutor da cítara no país e discípulo de Ravi Shankar, bem como a indicação ao Grammy em 2007 por um de seus cd's, cadinhos entre os diversos gfneros e estilos musicais do Oriente e do Ocidente (das composições eruditas da música hindu, aos covers, na cítara, de Hendrix, Sabbath etc., do repertório autoral, a flertar com o techno/lounge, às parcerias com emboladores de coco nordestinos e uma infinidade de outros prismas de sua poliédrica obra musical).

Os necrológios também referendaram a proximidade de Marsicano com os concretistas paulistanos, sendo ele amigo de Haroldo de Campos, com quem desenvolveu projetos criativos que uniram música e poesia. Contudo, uma curta, porém expressiva produção ligada ao universo literário foi deixada de lado e muito mais poderia ser dito acerca das explorações ficcionais de Alberto Marsicano, geralmente deixadas em segundo plano por sua música de qualidade (basta ouvir o cd autoral Electric Sitar, um de meus favoritos, para conferir isso) e, também - e não de forma negativa -, pela postura meio excêntrica que sempre inspirou os que tiveram o privilégio de conhecê-lo pessoalmente. Marsicano era não apenas um grande cronista,

\footnotetext{
${ }^{1}$ Doutor em Letras pela Universidade Federal de Pernambuco (UFPE), Recife, Pernambuco; Professor do Departamento de Letras da UFPE; Coordenador do Belvidera - Núcleo de Estudos Oitocentistas, junto ao Departamento de Letras da UFPE. Endereço eletrônico: bosquesdamoira@gmail.com.
} 
mas também um genial contador de histórias que sempre enveredavam no insólito.

Em muitas conversas que tive com Marsicano, fiquei especialmente tocado pelo permanente interesse que nutria pelos autores românticos. Disse-me uma vez que, em meio ao fog londrino, um mendigo havia the presenteado com uma edição antiga de Songs of Innocence, de William Blake, e defendia o fato de que o visionarismo coleridgeano e quinceyano, bem como o panteísmo romântico típico da poesia wordsworthiana, repercutiriam vários ensinamentos do Ocultismo, passando uma tarde a me explicar tais relações, revelando-se profundo conhecedor da estética romântica. Marsicano tornar-se-ia um dos primeiros tradutores, ao lado de John Milton (tradutor e professor da USP), de muitos poemas ainda inéditos em língua portuguesa, alguns dos quais, poemas narrativos extensos, de Keats (Nas invisíveis asas da Poesia [Ed. Iluminuras, 2002]), Wordsworth (O olho imóvel pela força da harmonia [Ateliê Editorial, 2007]), Shelley (Sementes aladas: Antologia poética de Percy Bysshe Shelley [Ateliê Editorial, 2010]) e do próprio Blake (O casamento do Céu e do Inferno \& outros escritos [Ed. L\&PM, 2007]), este último, traduzido fora da parceria com o professor Milton. Sua relação com os poetas românticos, especialmente os ingleses, era redimensionada através de sua própria ânsia de visionarismo e sempre se referia aos autores desta série como se fossem verdadeiros magos. Poderse-ia acrescentar ainda um nome não propriamente romântico a essa lista, o de Rimbaud, que elevou o visionarismo de extrato coleridgeano a novos píncaros, analisado por Marsicano em sua obra Rimbaud por ele mesmo (Ed. Martin Claret, 1996), além do interesse pela poesia do Extremo Oriente (sendo Marsicano um dos tradutores brasileiros de Bashô), bem como seus estudos de cunho ocultista, a exemplo de $A$ Linha do Oriente na Umbanda (Ed. Madras, 2009) e Os ciganos na Umbanda (Madras, 2010), para termos uma noção básica da conjunção entre os interesses estéticos e metafísicos do universo da escrita marsicânica. Das estadias no Oriente - estudou cítara na Índia - , resultou uma obra de referência na bibliografia teórico- musical brasileira, A música clássica da Índia (Ed. Perspectiva, 2006) e, por conta de seu desaparecimento, Marsicano deixou inacabados, entre outros, um projeto de cd com leituras da poesia de Álvares de Azevedo ao som da cítara, um livro em que estudava as obras ocultistas de Aleister Crowley e a poesia de Fernando Pessoa, já em processo de escrita, além de várias crôni- cas inéditas que iriam compor um segundo volume das Crônicas marsicâni- 
cas. Acredito que os originais devam estar agora sob os cuidados de seus pais, aguardando alguma editora de visão.

Em minha opinião, é no primeiro livro publicado das Crônicas marsicânicas (Ed. L\&PM, 2007), que Alberto Marsicano nos revela seu melhor potencial ficcional, se considerarmos a crônica como gênero imaginativo mais do que simplesmente mimético, seu conjunto ressaltando muitas influências românticas. Suas crônicas foram escritas e, posteriormente, reunidas, sob o influxo daquele Romantismo cioso de imaginação e (des)construção, autorreferente sem cair num puro solipsismo, criador de novas formas que revelam e refletem seus próprios mecanismos, bem co- mo de uma certa verossimilhança interna cara aos territórios do fantástico e do insólito.

As Crônicas marsicânicas poderiam ser elencadas dentro do gênero de viagens imaginativas, enformado ao longo dos séculos por obras paradigmáticas de Luciano de Samósata a Garrett, passando por Sterne, de Maistre e tantos outros autores que ampliaram a dinâmica descritiva própria às narrativas de viagem com seu próprio estro imaginativo, a transubstanciar lugares, tempos e acontecimentos com diversas intencionalidades, das discussões moralistas às experimentações do mais puro nonsense. Marsicano é mais um destes linguajeiros, viajantes da linguagem, mesmo que não se exima de visitar empiricamente os lugares distantes que descreve, eternamente atento às potencialidades criativas do insólito e do nonsense.

$\mathrm{Na}$ realidade, as Crônicas marsicânicas podem ser compreendidas como um álbum sinestésico mais do que efetivamente descritivo. A linguagem que evoca a viagem acaba se evolando neste mesmo processo, entornando-se sobre si e criando uma obra aberta, em que a dicção lírica e os procedimentos narrativos e modalizações típicas do poema em prosa diluem muitas vezes todo o senso tradicional de linearidade diegética (não à toa, o protagonista das crônicas "dreambula" pelas cidades que experiência mais do que descreve). Por outro lado - modus operandi tipicamente ro- mântico -, observa-se sempre a união destes aspectos poéticos, sublimes, com outros efetivamente grotescos, nas diversas maneiras como o humor é trabalhado na narratividade que ainda subsiste em meio às setenta e duas pequenas crônicas que compõem a obra, do chiste autorreferente, a um tempo poético e filosófico, ao "causo", da piada e trocadilho infames às paródias, do insight associado por Marsicano ao "assistemático, aberto e não-codificável pensamento Zen" (p. 44), típico dos haikais, à iconoclastia dos outsiders etc., numa perfeita noção de binomia (neo)romântica. Há 
todo um jogo de claro-escuro garantido pela disposição das crônicas no livro, os instantes filosóficos e poéticos sendo desconstruídos/reconstruídos continuamente pela ironia e o humor. De fato, a delicada presença da poesia na obra - poesia autoral ou traduções realizadas por Marsicano, recriadas dentro de contextos específicos (assim, a tradução do "Barco ébrio" rimbaudiano acaba servindo de metáfora às viagens do narrador e, mais ainda, ao seu próprio visionarismo) - , associada às sugestões sinestésicas operadas pelas experiências musicais e sensoriais do cronista, não eclipsam esta faceta verdadeiramente humorística das Crônicas, assegurando um permanente interesse por parte do leitor, que vivencia os choques de contrários. Características, mutatis mutandis, semelhantes às detectadas por Victor Hugo nas obras shakespearianas, a fundirem, criativamente, num "mesmo alento, o grotesco e o sublime, o terrível e o bufo, a tragédia e a comédia" (HUGO, 2007, p. 40). As Crônicas marsicânicas, um texto genuinamente contemporâneo, continuam referendando a perenidade estética do "Fragmento 116" de F. Schlegel, que afirma a necessidade de

[...] reunir todos os gêneros separados da poesia e pôr em contato poesia, filosofia e retórica. Ela [a obra romântica] quer e deve também misturar e fundir poesia e prosa, inspiração e crítica, poesia de arte e poesia da natureza, tornar a poesia viva e sociável, e a sociedade e a vida poéticas [...]. Pode se perder assim naquilo que descreve, a ponto de fazer pensar que seu único fim é caracterizar os indivíduos poéticos de todos os tipos; e contudo ainda não há qualquer forma capaz de expressar a totalidade do espírito de um autor: de modo que muitos artistas que desejavam apenas escrever um romance acabaram nos fornecendo um retrato de si mesmos [...] (SCHLEGEL, 1987, p. 54-55).

Assim, a escrita hipoteticamente autobiográfica das Crônicas não visa o registro conclusivo dos fatos, o olhar mimético aos diversos loci e acontecimentos (quando muito, entrevê-se o sketch, num ou mais episódios recortados da viagem), mas a sugestão de atmosferas, por meio da linguagem, como fica claro numa das andanças do narrador pela Espanha:

Pego a cítara e inicio o Raga da manhã Bhairavi. A música indiana nos ensina como transmutar a onda sonora num preciso matiz cromático e vice-versa. Toco sob a estrutura orgânica de um domo ornado com mosaicos de um branco profundo e intenso.

O som reverbera na tiffânica campânula art nouveau. Olho pra cima e noto que a incidência da luz nos alvos azulejos os tinge de tênues matizes de púrpura, turquesa e amarelo. 
No crepúsculo retorno pelas ruelas do Barrio Chino. À luz violeta do ocaso, degusto um gole de absinto pra rebater no [bar] Marseille. A Plaza Real incandesce à flama fulva do flamenco. Numa cena digna de Buñuel, deparo com uma cigana gritando:

- La Plaza Real no es mas real! (MARSICANO, 2007, p. 11-12).

Da mesma forma, vagando pelas praias de Cartajena, na Colômbia, o olhar visionário se alça a uma noção de infinito que também tem muito de romântica:

Após mirar a cidade das muralhas do forte colonial de San Felipe, vagueio descalço e despreocupado pela fria maré. A areia molhada ecoa meus passos ao suave metrônomo das marolas. Vislumbro ao longe um pequeno objeto na beira d'água.

Ao chegar, detenho-me ante a insólita imagem: um bracinho de boneca, jogado na areia, aponta o mar!

É decerto um mero pedaço de plástico. Mas no fundo percebo algo nele extremamente metafísico: um sinal apontando o além-mar, o infinito! (p. 37).

Num texto em que se observa uma experiência genuína e amálgama entre a poesia e espiritualidade orientais e o mais anárquico espírito iconoclasta dos autores beatniks (apenas para citar um dos vários 'dualismos não excludentes' presentes ao livro), em que a mística descrição da cerimônia japonesa do Zendô, onde se cogita qual será o som de uma harpa sem cordas, é substituída logo adiante por outra, uma "gira abissal", em que um médium umbandista incorpora o Caboclo Ubirajara no porão de uma casa, a arrebentar garrafas de aguardente nas paredes (e a escrita marsicânica acusa hilariamente aí uma "action painting do abismo"), muito frequente- mente o leitor se encontrará adentrando os umbrais do insólito.

Este se presentifica mais comumente através do grotesco, do inusitado, do nonsense, ao menos nas perspectivas/modalizações em que estas categorias se aproximam do riso (e não do sobrenatural), já que o universo sinestésico proposto pelas Crônicas assegura a euforia no trato com o real e não grandes choques contra ele. Do ponto de vista desta percepção do insólito, criado a partir dos interstícios do próprio real, as Crônicas marsicânicas poderiam também ser consideradas exemplos de literatura picaresca na literatura brasileira, por conta da frequente permanência e reiteração de situações esdrúxulas e inverossímeis, mas possíveis. Contudo, a compreensão de real de Marsicano, personagem principal de todas as suas crônicas, acaba sendo fantástica por si mesma, pela seminalidade e quantidade de 
situações, fenômenos etc, que o deslocam às últimas fronteiras da verossimilhança.

Os temas e acontecimentos ligados a esta vertente do insólito são inúmeros. Na crônica escrita em Bombaim, fala-se a respeito do serviço de quarto do decadente e perigoso Prince Hotel, dirigido por um sósia do cantor homônimo. Num vôo em Londres, descreve-se um acontecimento que o autor presencia, de suspeita de bomba, com traços surrealistas à Buñuel e Almodóvar, repleto de trocadilhos infames. No planetário de São Paulo, discute-se uma briga entre o cientista responsável pelo lugar e personagens esdrúxulos que defendem a Astrologia. Em Marrakesh, o autor conta como foi confundido com um espião por estar fotografando as manobras da força aérea local e se livrou da prisão declinando o nome dos jogadores da seleção brasileira de 1970. No Rio de Janeiro, narra as aventuras num parque de diversões dominado por "sete anões ravers". Em Leeds, o encontro com Frank Zappa e a revelação dos liames entre a música e a escultura de maneira insólita. Novamente em São Paulo, descreve, com genial humor, como foi expulso do espetáculo de um comediante popular, estando sob o efeito de estupefacientes, num teatro de subúrbio e, em seguida, como passou uma noite na mesma casa em que estava hospedado, disfarçado, Joseph Mengele. Em Bruxelas, dá-se o inusitado num encontro com um homem que lhe faz um convite intergaláctico:

[...] Como o lugar está lotado, um senhor de terno e chapéu pede para sentarse à minha mesa. De aparência circunspecta e surreal, ele parece ter saído de um quadro de René Magritte.

Ficamos em silêncio por mais de quinze minutos. De repente, num desdobrar de folhas, ele abre um grande mapa. Com o canto dos olhos dou uma furtiva espiadela:

Uma carta celeste! O curioso personagem apontando para as Plêiades me segreda:

- Estou partindo para esta constelação, você quer ir também?

Lembrei-me de um francês que tinha sido abduzido por alienígenas e que declarou na Paris-Match que os havia visto em trajes terrestres semanas antes do ocorrido numa fila de cinema!

Ele esperava inquieto a resposta:

- Amigo - disse-lhe - , obrigado, mas acho que ficarei por aqui...

Calmamente ele guardou o mapa, ergueu-se e, ao dar os primeiros passos, não pude deixar de indagar:

- Mas como o senhor vai para lá?

Fitando-me fixamente, ele solene proclamou:

- Tenho a chave do espaço! 
E desapareceu na bruma da forte chuva... (p. 30-31).

Há também os momentos em que o riso e a poesia das crônicas não confrangem os instantes de puro horror, em trechos que invertem a polaridade do real, passando-se a acusar a presença de um estranho e inquietante baseados no oculto. A exemplo da ocasião em que, retornando de sua viagem a Cartajena, onde contemplou visionariamente (sublime) a imagem

do infinito num bracinho de boneca, passa a experienciar o inquietante (grotesco sobrenatural): "Chegando a São Paulo, um arrepio percorreu-me a espinha quando abria o portão. Apontando a entrada de minha casa, jogado no chão, dispunha-se outro bracinho, o esquerdo!" (p. 39). Tem-se aí uma vertente do grotesco em que se acusa a fratura do natural, gerador de estranhamento, típica do horror literário, em todo o caso, a reafirmar aquela binomia de genealogia romântica observada anteriormente nas Crônicas. Em outro momento, narra o encontro mágico com entidades da mi- tologia hindu, estando na cidade de Patna (Índia), numa crônica fantástica e imaginativa:

Caminho pelo Ganges. As caudalosas e barrentas águas escorrem turbulentas pelas margens encharcando os templos milenares. Na estação chuvosa das monções espessas nuvens negras erguem-se ameaçadoras sobre a paisagem. Passo por uma pequena aldeia onde tomo uma mistura de leite com chá e especiarias com os simpáticos e falantes moradores locais. Sigo em frente e, através de uma pequena picada que margeia o caudaloso rio, contemplo o anoitecer [...].

Precipita-se uma violenta tormenta de granizo e corro através de um espesso matagal em busca de abrigo. Vejo ao longe um palácio abandonado e à luz dos relâmpagos cruzo um pequeno lago de pedra vazio coberto de folhas secas. O muro está em ruínas e do portal só restaram os grandes pilares. No amplo salão tudo se encontra desolado e coberto de poeira. Deito-me no chão contemplando as curiosas configurações de luz relampeando através das vidraças quebradas. Sinto um forte aroma de sândalo. Um gato mia e ouço o inquietante ruído de passos, entrevendo vultos saindo da negra treva: são duas aldeãs que me saúdam dizendo que ali poderia pernoitar e abrigarme da tempestade. Uma distinta senhora de idade, muito bem vestida com um sari branco e dourado, apresenta-se como a dona da casa e oferece-me toda a tradicional hospitalidade do povo indiano. Cansado como estava, adormeci como uma pedra e, aos primeiros raios do sol, abandonei o local. Caminhei de volta a Patna passando novamente pelo pequeno povoado. Os aldeões estavam muito preocupados pois várias pessoas haviam morrido afogadas na inundação provocada pela tormenta da véspera. Contei-Ihes que nada acontecera comigo porque passara a noite sob a generosa hospitalidade das bondosas senhoras da mansão abandonada. 
Eles então gelaram: as três haviam morrido há mais de cinquenta anos (p. 147148).

Estes dois exemplos configuram mais uma das vertentes do insólito na obra. Diversos das cenas jocosas descritas anteriormente - a gerar uma espécie de grotesco situacional - , mas a reiterar uma visão singular do cotidiano brasileiro e universal, atestando outra vez a posição única de Alberto Marsicano - que, para nossa saudade, recebeu recentemente sua "chave do espaço" - no território fecundo, mas geralmente conservador e mimético, da crônica nacional.

\section{REFERÊNCIAS}

HUGO, Victor. Do grotesco e do sublime. Trad. Célia Berrettini. 2. reimp. da 2. ed. de 2002. São Paulo: Perspectiva, 2007.

MARSICANO, Alberto. Crônicas marsicânicas. Porto Alegre: L\&PM Editores, 2007.

RIMBAUD, Arthur. Poesia completa. Trad. e notas Ivo Barroso. 3. ed. Rio de Janeiro: Topbooks, 1995.

SCHLEGEL, Friedrich. Fragmentos do Athenaeum [excertos]. In: LOBO, Luíza. (Org.). Teorias poéticas do romantismo. Trad. Luíza Lobo. Porto Alegre: Mercado Aberto, 1987, p. 50-73. 